\title{
Über die Solidarität unter den chirurgischen Fachgebieten oder „Wer nicht mit am Tisch sitzt, landet auf der Speisekarte“"
}

\author{
About Solidarity among Surgical Specialties or "If you don't Sit at the Table, \\ You are on the Menu"
}

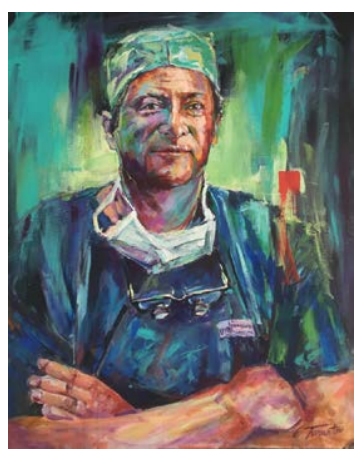

R. E. Giunta
Liebe Leserinnen und Leser, als Plastischer Chirurg „wächst“ man in der Gemeinschaft der Chirurgen aller Fachgebiete wie in einer „Familie“ auf. Man lebt in dem Bewusstsein, dass das Fach Plastische Chirurgie ein Bestandteil der Chirurgie ist. Gleichzeitig ist man fest davon überzeugt, dass die chirurgischen Fachgebiete untereinander eine starke Solidargemeinschaft - die Einheit in der Chirurgie - bilden (॰ Abb. 1).

Je mehr man jedoch hinter die Kulissen blickt, desto mehr verblasst dieses Bild und man stellt fest, dass Anspruch und Wirklichkeit häufig auseinanderklaffen und die chirurgischen Fachgebiete sich nicht immer gegenseitig unterstützen. Besonders die traditionell großen Fachgebiete sind hier nicht immer solidarisch mit den kleineren. Gerade die jüngeren Fachgebiete, wie etwa die Thoraxchirurgie, die Gefäßchirurgie und auch die Plastische Chirurgie haben hier oft einen schweren Stand. So muss auch das Fachgebiet Plastische Chirurgie seine Interessen behaupten. Nur allzu oft wird es von den traditionellen chirurgischen Fachgebieten als „Life Style Chirurgie“ oder „Schönheitschirurgie“ gleichgesetzt und daher als unbedeu-
Dear readers,

As a plastic surgeon you grow up in the community of surgeons of all specialties. You develop an awareness that the field of plastic surgery is an integral part of surgery. You strongly believe that the surgical specialties have built a strong community of solidarity among each other - the unity of surgery.

However, looking behind the scenes you will watch this notion fade away and you start noticing that your expectations and reality are far apart. Surgical disciplines support each other. Especially the large traditional specialties often fail to show solidarity with the smaller ones such as thoracic surgery, vascular surgery and plastic surgery, which often have a hard time.

The field of plastic surgery needs to assert its interests. Too often it is dismissed as "life style surgery" by the traditional specialties of surgery or placed on the same level as pure "cosmetic surgery" and is therefore categorised as insignificant not only in the public eye, but also among surgeons themselves $[1,2]$. Often this is due to the fact that surgeons ignore the fascinating achievements made in this specialist field - achieve-
Bibliography DOI http://dx.doi.org/ 10.1055/s-0042-104736 Handchir Mikrochir Plast Chir 2016; 48: 61-64 (c) Georg Thieme Verlag KG Stuttgart · New York ISSN 0722-1819

Correspondence Univ.-Prof. Dr. med. Riccardo E. Giunta

Abteilung für Handchirurgie Plastische Chirurgie und Ästhetische Chirurgie Klinikum der LudwigMaximilians Universität (LMU) München Pettenkoferstraße 8a 80336 München (c) fotomek/Fotolia.com. r.giunta@med.uni-muenchen.de

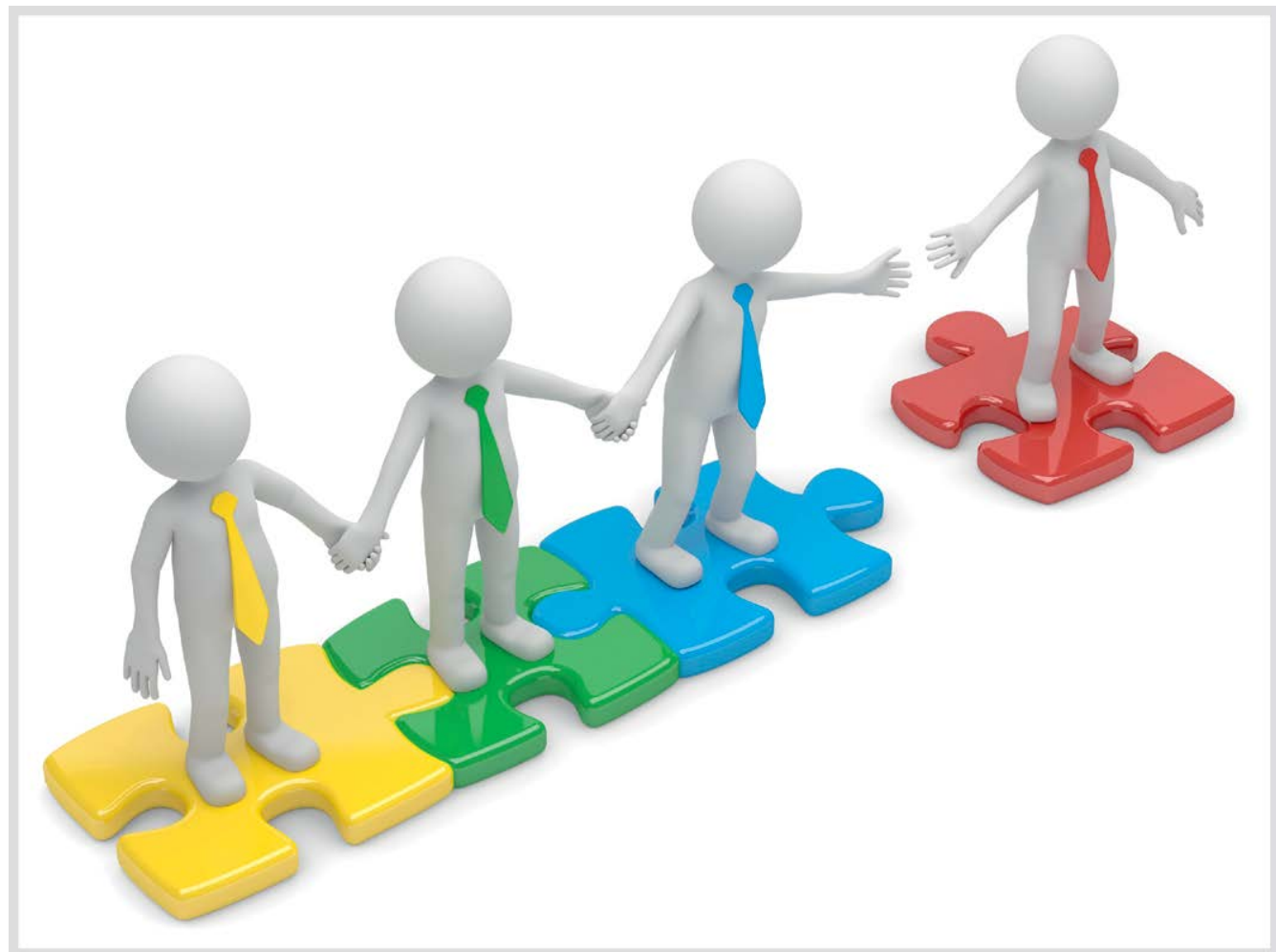

Abb. 1 Solidarität unter den chirurgischen Fachgebieten: Jüngere Fachgebiete werden von den etablierten Fachgebieten unterstützt (@ fotomek/Fotolia.com). 
tend abgetan [1,2]. Oft liegt der Grund in der Unkenntnis der eindrucksvollen Leistungen und rapiden Entwicklung des eigentlichen Fachgebietes in allen vier Säulen ( $\bullet$ Video 1 ), die es dem Plastischen Chirurgen ermöglichen, Patienten mit komplexen Problemsituationen dauerhaft eine deutlich bessere Lebensqualität zu verschaffen.

Bedauerlicherweise vertreten auch gerade jüngere Lehrstuhlinhaber der großen Fachgebiete wie Viszeralchirurgie oder Unfallchirurgie in diesem Zusammenhang oft veraltete, traditionelle Vorstellungen der Chirurgie, die keine Perspektive mehr für die gesamte Chirurgie des 21. Jahrhunderts sind.

Richtig ist natürlich schon, dass Plastische Chirurgie oft keine lebensrettenden Eingriffe durchführt. Dies gilt übrigens auch für die Mehrzahl der Indikationen in der Orthopädischen Chirurgie. Gleichzeitig ist aber auch das pure Überleben einer Operation längst nicht mehr das einzige Ziel in der Chirurgie. Für den Patienten macht es einen erheblichen Unterschied, ob er die Klinik mit einem durch eine Lappenplastik geretteten Bein oder mit einer Stumpfversorgung und einer Prothese verlässt. Gleiches gilt für eine funktionierende Hand gegenüber einer z. B. asensiblen, möglicherweise im Alltag funktionslosen Hand. Darüber hinaus bedeutet es für den Patienten durchaus einen Unterschied, ob er 30 Operationen für Vakuumversiegelungen bei einer chronischen Wunde mit dem Ziel der sekundären Wundheilung erhält und vielleicht erst dann zum Plastischen Chirurgen geschickt wird, obwohl genau dieser Weichteildefekt mit einer Lappenplastik oft mit einer einzigen Operation verschlossen werden könnte. Eine optimale Patientenbehandlung mit Plastischer Chirurgie wird so dem Patienten an vielen Kliniken vorenthalten. Neben einer nicht mehr zeitgemäßen Versorgung und der zeitlichen Verzögerung einer adäquaten Behandlung für den Patienten, entstehen dem Gesundheitssystem so deutliche Mehrkosten.

Plastische Chirurgie ist zur optimalen Patientenbehandlung in vielen Bereichen der Chirurgie nötig. Sie überschneidet sich mit vielen anderen chirurgischen Fachgebieten und ist daher an einer großen Universitätsklinik nicht wegzudenken. Dennoch hat sich seit Etablierung des Facharztes für Plastische Chirurgie im Jahre 1993 - also vor mehr als 20 Jahren - die universitäre Plastische Chirurgie in zu kleinen Schritten weiterentwickeln können. Von 35 deutschen Universitätskliniken weisen nur 11 eine eigenständige Klinik für Plastische Chirurgie auf [3]. Universitätskliniken mit einem Lehrstuhl für Plastische Chirurgie konnten gegenüber Organisationsstrukturen mit einem anderen Fachgebiet untergeordneter Plastische Chirurgie, eine um ein Vielfaches höhere akademische Effektivität längst nachweisen [3,4]. Die Ursachen für die langsame Entwicklung liegen oft auch in der mangelnden Unterstützung durch die anderen chirurgischen Fachgebiete, die das Fachgebiet Plastische Chirurgie gerne als Teil ihrer selbst ansehen und die Weiterentwicklung durch Einschränkung des Gestaltungsspielraums behindern. Wir Plastische Chirurgen werden gerne mit Sätzen wie „Das bisschen Plastische Chirurgie mach ich auch mit“ oder „Einen Finger replantieren kann ich auch selbst“ abgespeist. Diese Position wird zudem oft im klinischen Alltag gegenüber dem Klinikpersonal und auch z.B. gegenüber der Kaufmännischen Direktion vertreten. Hierdurch wird gezielt eine Meinung zu einem ganzen Fachgebiet geformt. Fast gewinnt man den Eindruck, dass das Fachgebiet Plastische Chirurgie manchmal bewusst aus dem Klinikumsbetrieb „geekelt“ werden soll. In der Realität dagegen besitzen fachfremde Kollegen auf Grund ihrer naturgemäß auf ihr Fachgebiet begrenzten Weiterbildung in der Regel keine Plas- ments which clearly improve the quality of life of patients with complex health problems. Unfortunately, even the younger university chairholders in traditional disciplines such as visceral surgery often represent a completely outdated image of surgery, which originated in the past century and provides no perspectives for surgery as a whole in the $21^{\text {st }}$ century.

It is certainly true that plastic surgery procedures are not a matter of life and death. However, this also often applies to most indications in orthopaedic surgery. Also, the goals of surgery today far exceed the mere survival of an operation. The chance to leave hospital with a leg saved by a flap certainly makes a huge difference for patients compared with the prospect of having to go home with an amputated leg. The same applies to a functioning hand compared with one that has lost its sensory function and may be useless in a patient's everyday life. Or think about patients who undergo 30 operations for vacuum therapy in a chronic wound with the objective of secondary wound healing before being sent to a plastic surgeon, although their soft tissue defects often could have been closed by a flap in a single plastic surgery procedure. Unfortunately, these cases are not uncommon, costing the health care system a lot of money in addition to the inadequate treatment and the treatment delay for the patient.

Plastic surgery overlaps with all other surgical specialties and is an integral part of a large university hospital. However, the development of academic plastic surgery has been fairly sluggish since plastic surgery was established as a surgical specialty in 1993, more than 20 years ago. Only 11 out of 35 university hospitals in German have an independent department of plastic surgery today [3]. It has long been proven that university hospitals with an independent department of plastic surgery have a much better academic performance than hospitals in which plastic surgery is a subordinated organisational structure $[3,4]$.

Among other things, this is due to the lack of support provided by the large surgical specialties, which have a tradition of viewing plastic surgery as a subordinated part of themselves and prevent this field from developing further by restricting its scope of action. Plastic surgeons are often fobbed off with comments such as "I'll do that little bit of plastic surgery on my own" or "I can replant a finger on my own" by representatives of the large surgical disciplines. This view is often communicated to all different levels of staff members, from nurses up to the Managing Director, and certainly shapes their opinion on this surgical field. You almost gain the impression that surgeons aim to remove this

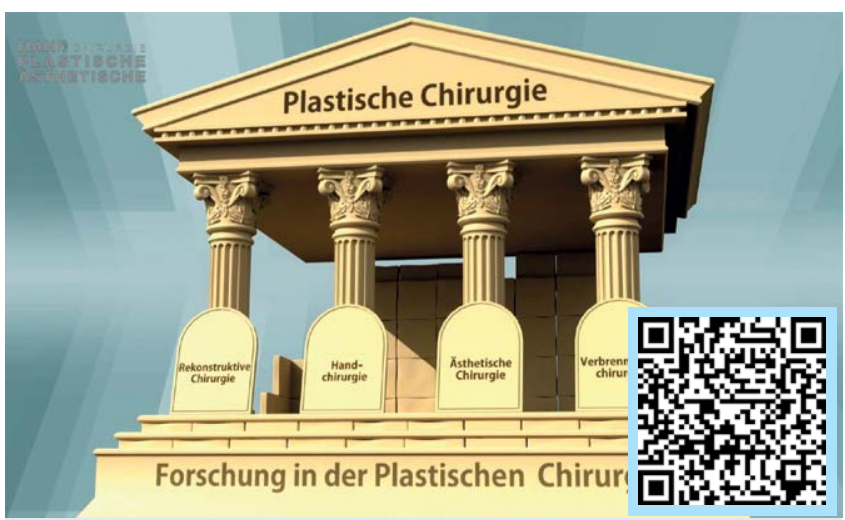

Video 1 Die vier Säulen der Plastischen Chirurgie (aus https://www. youtube.com/watch?v=AIDCoRI9xYQ mit Genehmigung). The 4 Columns of Plastic Sugery (from https://www.youtube.com/watch?v=xCgbsZ5ncKE with permission). 
tisch-Chirurgische Kompetenz. Tatsächlich besteht meist nur ein marginales Wissen über die eigentlichen Inhalte des Fachgebietes Plastische Chirurgie.

In diesem Kontext entstehen an einigen Universitätskliniken W2 Professuren für Plastische Chirurgie integriert in Kliniken etablierter chirurgischer Fachgebiete. Meist sind diese ohne eigene Ressourcenzuweisung ausgestattet und haben damit von vorneherein ein massives Handicap. Eine solche Entwicklung mit Einrichtung von Sektionen kann bestenfalls als „Alibi“ - Plastische Chirurgie angesehen werden, da sie den übergeordneten Fachgebieten doch zusichert, Inhalte, akademische Verdienste mit den entsprechenden Leistungszuweisungen (LOM) und Erlöse aus der klinischen Patientenbehandlung in ihren Fachgebieten zu halten. Dies stellt im Grunde keine solidarische, nachhaltige Unterstützung zur Weiterentwicklung des Fachgebiets Plastische Chirurgie dar, sondern dient in Wahrheit der Absicherung des eigenen Machtbereichs.

Die großen chirurgischen Fachgebiete können auch noch weniger Solidarität gegenüber der Plastischen Chirurgie zeigen: bspw. wird an einer Universitätsklinik in Deutschland zugelassen, dass sich die Unfallchirurgie 2 Plastische Chirurgen einstellt, obwohl eine eigene Klinik für Plastische Chirurgie am Universitätsklinikum existiert und sich daraus naturgemäß eine Konkurrenzsituation innerhalb einer einzigen Universitätsklinik ergibt. Ähnliche Tendenzen mit identischem Ziel sind vielerorts und gerade an den Universitätskliniken zu beobachten: Ein Plastischer Chirurg wird in der Gynäkologie oder Dermatologie in direkter Konkurrenz zur Plastischen Chirurgie des Klinikums eingestellt. An einer weiteren Universitätsklinik versucht ein großes chirurgisches Fachgebiet, sich mit dem Wechsel des Lehrstuhlinhabers für Plastische Chirurgie die Handchirurgie einzuverleiben. An der nächsten Universitätsklinik entscheiden Chirurgen der großen Fachgebiete gemeinsam, für die Plastische Chirurgie einen ganzen Standort aufzugeben. Dass dabei die medizinische notwendige Infrastruktur für eine optimale plastisch-chirurgische Patientenbehandlung von komplexen Fällen an einem Großklinikum verloren geht, bleibt völlig unberücksichtigt. Wiederum geht man lapidar von der falschen Vorstellung aus, dass komplexe Plastisch-Chirurgische Fälle gerade mal nebenher konsiliarisch und ohne relevante Infrastruktur mit behandelt werden können. Für eine adäquate Behandlung von komplexen plastisch-chirurgischen Fällen ist tatsächlich ein ganzes Team nötig.

Diese Beispiele zeigen, dass gerade in Settings mit untergeordneten Organisationsstrukturen die Plastische Chirurg in der Regel gar nicht am Tisch sitzt, wenn die großen chirurgischen Fachgebiete solche Entscheidungen über klinische Inhalte, klinische Infrastruktur oder seine akademischen Ressourcen entscheiden. Elof Eriksson, der die Plastische Chirurgie an der Harvard Medical School in Boston, U.S.A. leitet, hat die Situation exzellent mit dem Satz „If you don't sit at the table, you are on the menu“ auf den Punkt gebracht.

Als Herausgeber des Plastischen-Chirurgischen Bereichs der Zeitschrift freue ich mich ganz besonders, dass er zu diesem Heft eine wichtige Übersicht zur Thematik und zur speziellen Situation in den U.S.A. beiträgt [5]. In den Vereinigten Staaten ist es auf Grund der Anerkennung der breiten und profunden Weiterentwicklung der Plastischen Chirurgie durch die anderen chirurgischen Fachgebiete erfreulicherweise im letzten Jahrzehnt zu einem deutlichen Anstieg der unabhängigen Einheiten gekommen. specialist field from clinic operations. In reality, non-plastic surgeons usually have no expertise in this field. They only have some marginal knowledge of what plastic surgery is actually about.

In this context, some university hospitals in Germany have introduced "W2" professorships for plastic surgery, which, rather than being independent, are integrated in departments of established surgical specialties such as trauma surgery. Most of these professorships are not equipped with their own proper resources, which means that they are handicapped from the beginning. The establishment of such integrated sections is no more than tokenism for the field of plastic surgery, since the superordinate specialties can rest assured that they will retain the clinical content and academic merits and continue to receive the associated economic benefits (performance-related resource allocation) as well as the revenues from their own patient treatment. This is certainly not an act of solidarity meant to support the advancement of plastic surgery, but rather serves to protect the traditional specialties' own sphere of influence.

However, in some cities established surgical disciplines have demonstrated even less solidarity. For example, a university hospital in Germany has allowed its department of traumatology to employ 2 plastic surgeons, although the hospital has its own department of plastic surgery in place. This naturally leads to a competitive situation within one and the same university hospital. Similar situations have been observed in many other places, especially in university hospitals, all of them having been established to weaken the specialty of plastic surgery in terms of academic content: For example, plastic surgeons have been employed in a department of gynaecology or dermatology in direct competition with the department of plastic surgery of the same hospital. At another university hospital, the head of a large surgical department tried to annex the department of hand surgery when the head of plastic surgery retired. At yet another university hospital, surgeons of traumatology and visceral surgery jointly decided to abandon the entire department of plastic surgery, thereby disrupting its interdisciplinary connection to the other disciplines. What is entirely disregarded here is the fact that such actions lead to the loss of the medical infrastructure needed for optimal plastic-surgical patient treatment in complex cases exceeding the expertise of other specialist fields. Once again, surgeons seem to share the misconception that complex cases may simply be managed by a consultative referral.

Especially in settings where plastic surgery is a subordinated organisational structure, the plastic surgeon is usually not sitting at the table when the large surgical specialties decide about clinical content, clinical infrastructure or academic resources. Elof Eriksson, chairing plastic surgery at Harvard Medical School in Boston, has put the whole situation in a nutshell saying: "If you don't sit at the table, you are on the menu."

I am glad that he will make an important contribution in editor's role of the journal on this subject matter and the situation in the United States, [5] where the past decade has seen an increase in independent units of plastic surgery thanks to the recognition of the profound advances made in this field.

Dear readers,

On behalf of the unity of surgery and in the firm awareness that plastic surgery is a rapidly evolving and increasingly important part of surgery, I am calling on the representatives of the traditional surgical specialties to treat our relatively young surgical 
Liebe Leserinnen und Leser,

im Sinne der Einheit in der Chirurgie und dem festen Bewusstsein, dass Plastische Chirurgie ein sich rasch entwickelnder und zunehmend an Bedeutung gewinnender Teil der Chirurgie ist, möchte ich die Vertreter der etablierten chirurgischen Fachgebiete dazu aufrufen, unser junges Fachgebiet im klinischen Alltag an den Universitätskliniken solidarisch und fair zu behandeln und uns bei der Einrichtung von vollständig eigenständigen Lehrstühlen für Plastische Chirurgie an Universitätskliniken in den nächsten Jahren zu unterstützen. Die großen chirurgischen Fachgebiete haben hier ähnlich der Situation in einer „Familie“ die wichtige Aufgabe, ihre „Kinder“ nachhaltig zu unterstützen und zu fördern ( $\bullet$ Abb. 1). Es kann nicht sein, dass sie im Alltag ähnlich wie Kinder im Sandkasten ständig versuchen, ihrem kleinen Bruder die Schaufel - also etwa stationäre Betten, OP-Saalkapazitäten, Räumlichkeiten oder Anderes - wegzunehmen, weil dies der vermeintlich einfachere Weg ist. Wir Chirurgen müssen, wenn wir Bedarf an zusätzlichen Ressourcen haben, diese von außen, zusätzlich für die gesamte Chirurgie gewinnen. Dieses Verhalten wäre unwürdig für die „Familie“ der Chirurgie und würde auch im Widerspruch zu deren Einheit und dem Verständnis einer Solidargemeinschaft stehen.

Ich freue mich daher ganz besonders, dass ich auch Mike Neumeister aus Springfield Illinois dazu gewinnen konnte, seine Erfahrungen als Leiter der Plastischen Chirurgie und gleichzeitig Chef des Departments für Chirurgie an einer großen Universität der U.S.A. zusammenzufassen [6]. Er beschreibt exzellent wie die Kreativität und visionäre Innovationskraft der Plastischen Chirurgie in guter interdisziplinärer Zusammenarbeit auf Augenhöhe an seiner Universitätsklinik der gesamten Chirurgie zu Gute kommt. Solche erfolgreichen Situationen des wechselseitigen Respekts und der gemeinsamen interdisziplinären Solidarität gibt es erfreulicherweise auch an einigen Universitätskliniken in Deutschland. Mögen diese vorbildhaft gut funktionierenden Kliniken für Plastische Chirurgie für die vielen anderen Universitätskliniken in Deutschland ein gutes Beispiel dafür sein, wie das Fachgebiet Plastische Chirurgie auf Augenhöhe mit den anderen chirurgischen Fachgebieten ein Universitätsklinikum, eine medizinische Fakultät und auch die Gemeinschaft der chirurgischen Fachgebiete bereichern und gleichzeitig eine zeitgemäße, optimale Versorgungssituation für den Patienten absichern kann.

München, im März 2016

\section{Riccardo Giunta}

discipline with solidarity and fairness in the daily clinical routine at university hospitals. Please help us establish fully independent departments of plastic surgery at university hospitals in the coming years. Similarly to the situation in a "family", the large surgical specialties are entrusted with the important task of providing sustainable support for their "children". It is unacceptable if they behave like small children in a sandbox who constantly try to take away their little brother's shovel (meaning inpatient beds, operating room capacity, premises etc.). If the large specialties need more resources, they must obtain them from an external source and add them to the community of surgery. Resources should definitely not be withheld from or even taken away from the smaller specialties just because this is considered the easy way out. This behaviour would be unworthy of a functioning family of surgery and contradictory to a community of solidarity ( $\bullet$ Abb. 1).

Therefore, I am particularly happy to have been able to win Mike Neumeister from Springfield, Illinois, to contribute his experience as the head of plastic surgery and chief physician of the department of surgery at a large university in the United States [5]. He excellently describes how the creativity and visionary innovation of the department of plastic surgery and the fair play at his university hospital benefits surgery as a whole. It is good to see that some university hospitals in Germany also practice mutual respect to plastic surgery and successful interdisciplinary solidarity in surgery. Let them all be a role model for the large number of other university hospitals in Germany, showing them how a department of plastic surgery working on equal terms with the other surgical specialties can enrich a university hospital and a medical school and provide optimal care for patients [6].

Munich, March 2016

Riccardo Giunta

\section{References}

1 Giunta RE, Schmidt-Tintemann U. Was soll Plastische Chirurgie? Handchir Mikrochir Plast Chir 2013; 45: 191-192

2 Giunta RE. Gedankenaustausch zum 90sten Geburtstag von Frau Prof. Ursula Schmidt-Tintemann: Was soll Plastische Chirurgie? Was soll sie nicht? Handchir Mikrochir Plast Chir 2014; 46: 203-205

3 Schubert $C D$, Leitsch S, Haertnagl $F$ et al. Vorteil durch Eigenständigkeit? Analyse der Publikationsleistung der universitären Plastischen Chirurgie in verschiedenen Organisationsstrukturen. Handchir Mikrochir Plast Chir 2015; 47: 213-221

4 Alawi SA, Bohr S, Stromps JP et al. Eine Analyse der Forschungsaktivität universitärer Kliniken für Plastische Chirurgie im nationalen Vergleich: Eine systematische 5-Jahres Evaluation der Forschungsaktivität in Deutschland. Handchir Mikrochir Plast Chir 2016 Feb 2

5 Eriksson E. Academic Status of plastic surgery in the United States and the Relevance of Independence. Handchir Mikrochir Plast Chir 2016; 48: 65-68

6 Neumeister MW. Kann der Plastische Chirurg Leiter des Departments für Chirurgie an einer Universitätsklinik sein?...Das funktioniert wirklich? Handchir Mikrochir Plast Chir 2016; 48: 69-72 